\title{
Anatomical Structures Preservation Using Plastination Techniques
}

\author{
SORIN LUCIAN BOLINTINEANU11, ELENA POP¹, GEORGE STANCUㄹ, GHEORGHE STANCU1, MONICA ADRIANA VAIDA ${ }^{1 \#,}$ \\ ALINA MARIA SISU1*\#, JENEL MARIAN PATRASCU2, SORIN FLORESCU² \\ ${ }^{1}$ Victor Babes University of Medicine and Pharmacy, Department of Anatomy and Embryology, 2 Eftimie Murgu Sq., 300041, \\ Timisoara, Romania \\ 2 University of Medicine and Pharmacy Victor Babes, IInd Orthopaedic Clinic, 2 Eftimie Murgu Sq., 300041,Timisoara, Romania
}

\begin{abstract}
A constant situation present in the anatomy laboratories is represented by the cadavers preservation resulted from dissection. The main requirementfor this process is the use of formaldehyde which is a toxic substance probablyincluded in the class of carcinogenic substances. Large specimens resulted from dissection process, such as limbs or trunks, can be preserved only in large containers filled with formaldehyde and for limited periods of time. To remove these issues we used the anatomy laboratory in order to be able to preserve the first sustainable plastinated anatomical specimens. In our study have been used 8 adult human bodies (partial and complete), 6 females and 2 males, aged between 62 and 73. We have removed and dissected brains, upper limbs, kidneys and livers. They have undergone preservation process of plastination.
\end{abstract}

Keywords: plastination, preservation, S10 Biodur technique.

Plastination is a sustainable method of conservation, in which dissected anatomical parts are impregnated with silicone, making them as teaching material with prolonged time usage $[14,16,17,19,20]$.

S3 Biodur, S6 Biodur and S10 Biodur are the most commonly used agents for tissue plastination. Chaynes et all. [1] decided to fully characterize these products by standard analytical methods: multi nucleus magnetic resonance, infrared spectroscopy and size exclusion chromatography. These experiments have shown that S10 Biodur is a polydimethylsiloxane with a molecular weight of 27,200, S6 Biodur is tetraethoxysilane, and S3 Biodur is a mixture the main component of which is dibutyltindilaurate [1].

Using these methods of preservation, an aim is met: removal of formaldehyde as a means of permanent preservation [2, 3]. Anatomical preparations thus obtained are handled and stored under favourable conditions. All these favourable considerations for implementing plastination as a method of preserving anatomical preparations are subject to the interaction of at least three factors:

- The existence of an accredited plastination laboratory, - Specific equipment to achieve the desired plastinated preparations,

- Knowledge of complex plastination techniques.

\section{Experimental part}

Materials and methods

In our study were used 8 adult human bodies, 6 females and 2 males, aged between 62 and 73 . There were removed, dissected and plastinated 5 bodies that have undergone this process 70 days instead of 75, as is standard. There have been removed 6 cerebral hemispheres, one liver. Upper limbs were plastinated between 80 and 90 days, being taken from 2 male bodies. The body with shortest possible postmortem interval (2-10 days) is desirable in order to avoid the effects of the autolytic degeneration [2]. We have formolized bodies with a postmortem interval between 30-68 days. The

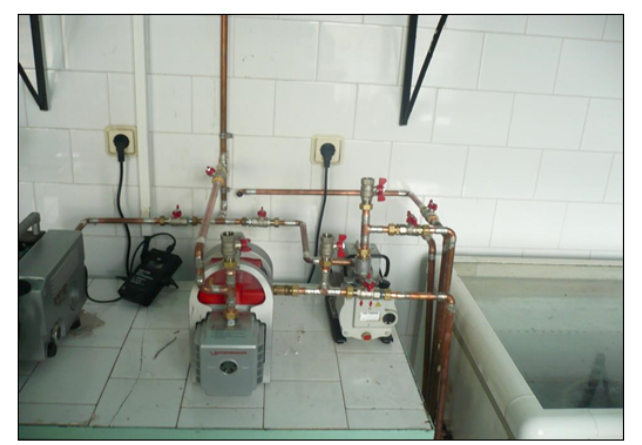

Fig.1 Plastination laboratory. Vacuum pump and forced impregnation system.

development of plastination requires certain equipments of minimum necessity, as follows: industrial refrigerators of high volumetric capacity that can handle temperatures between -25and-30 degrees for a constantindefinite period of time (fig. 1).

Basically the beginning of the plastination process represents a continuously development in certain steps of activity such as: formaldehyde fixation, dehydration using acetone, forced impregnation in Heidelberger boiler using mixed S10 and S3 Biodur solutions, treatment with evaporation gas S6 Biodur solution and nylon wrapping procedure. The average time of a preparation summing all these steps in order to obtain a fully anatomical plastinated piece is estimated on the base of the obtained results and is considered to vary between 75 and 90 days $[4,5]$. Forced impregnation mainly addresses to the pressure of the mixture of S3 Biodur and S10 Biodur which will gradually decrease along a period of 10 to 14 days from $760 \mathrm{mmHg}$ to $0 \mathrm{mmHg}$. This process is carried out at -25 degrees.

In practical terms, the plastination process implies the following steps: 
- the fixation of the specimen. Anatomical parts are fixed in $10 \%$ formaldehyde solution in order to prevent the autolysis and tissue damage. This first step is important for plastination, whereas a poor fixation or delayed preparation process burdens the well development of the process of dissection [6, 7];

- preparation of anatomical dissection parts. Previously fixed parts in 10\% formaldehyde solution will be dissected properly, where one will understand the term of dissections as being the operation to depict the relationships between anatomical structures or regions, without changing their structure;

- dehydration. This stage involves replacing the water contained in tissues with an organic solvent which is acetone. We follow the cold substitution technique, at a temperature of $-25^{\circ} \mathrm{C}$, using refrigerators of great power;

- forced impregnation. Forced impregnation represents the central stage of the plastination process and consists in replacing acetone with a mixture of S10 Biodur and S3Biodur solution, the ratio is 100/1, at a temperature of $-25^{\circ} \mathrm{C}$. This step can be done at the room temperature (hot) or low temperature of $-25^{\circ} \mathrm{C}$. This technique involved dehydration of formalin - fixed specimens in acetone at $-20^{\circ} \mathrm{C}$ for 3 weeks followed by immersion in a mixture of S10/S3 (ratio $100: 1$ ) at $-20^{\circ} \mathrm{C}$ for 1 week, standard technique [4]. We have used the technique of cold impregnation at a temperature of $-25^{\circ} \mathrm{C}$, which provides one the assurance that the obtained specimen is characterized with high accuracy, quality and durability;

- gas treatment. The anatomical specimen which has been impregnated is placed in a closed room together with a container which contains S6 Biodur solution. With the help of a pump the $\mathrm{S} 6$ liquid Biodur is vaporized over the plastinated piece.

\section{Results and discussions}

Our work in the Department of Anatomy and Embryology (Victor Babes University of Medicine and Pharmacy from Timisoara) aimed to produce anatomic structures used for learning and teaching students. The formolized bodies are toxic and have only several years of life, while the plastinated structures are odourless, timeless, non toxic and the structures could be seen at their real dimensions. The real disadvantage of the formaldehyde is the long exposure of the teachers and students during teaching process. Having plastinated structures, this disadvantage is eliminated.

Dissection- macroscopic and mezoscopic (magnifying glass)- (classical method of teaching anatomy) precedes plastination. Without a proper and professional dissection of the anatomical piece, plastination can become not only a pointless activity but also a high-cost method.

Reiderer et all. (2014) [8] found that for better differentiation of gray and white brain matter, the Prussian

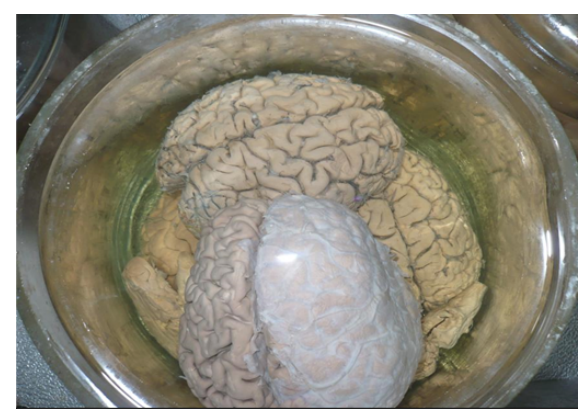

Fig.2. Brain dehydration: Cerebral hemispheres with median interemispheric sulcus (1) and meningeal layers (2) blue staining procedure can be used as described by Barnett et all (1980) [18]. Further research is in the line to innovate protocols for plastination of brain slices.

The first obtained results are favourable. Satisfactory outcomes regarding general appearance, colour and consistency are achieved and, moreover, the preparation for obtaining the anatomic pieces can lack of formaldehyde use, therefore the anatomical pieces can be stored and deposited. This aspectsets the stage for creating collections of anatomical preparations which have great addressability to a large target audience in the teaching and research process $[9,10]$. Yet, with certainty the most important element in the success of plastination is represented by the human factor. Plastination which is a modern method of preserving anatomical preparations should and is associated with dissection (figs. 2-4).

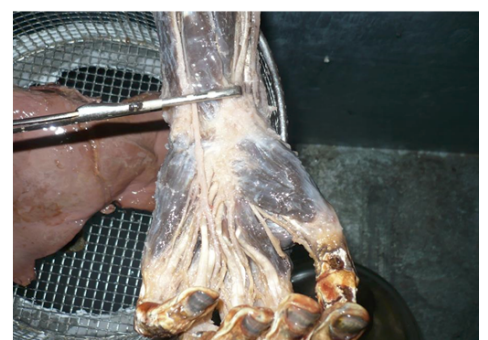

Fig.3. Upper limb and liver- forced impregnation. On the clip: median nerve. Could be seen: muscles of the thenar eminence (1), flexor digitorum superficialis muscle tendons (2), muscles of the hypothenar eminence (3), and liver ( diaphragmatic surface)

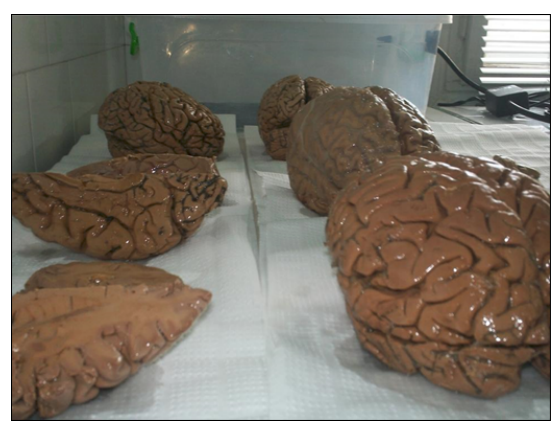

Fig.4. Gas treatment (cerebral hemispheres-slices)

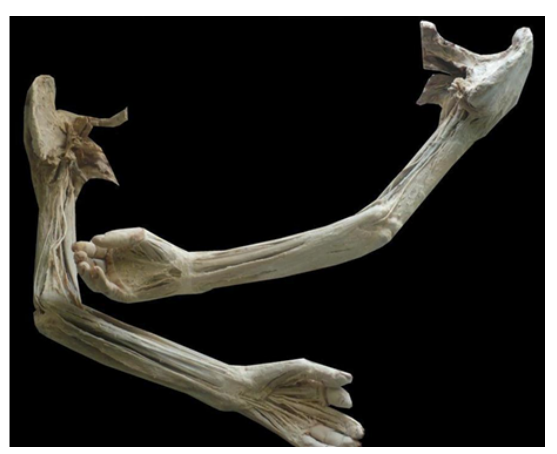

Fig.5. Upper limbs: could be seen the vessels and nerves of the upper limbs and the joints

The plastinated specimens, obtained over the period of 7 years in our department, have retained their life-like appearance without any decay. They are resistant to fungal growth and atmospheric variations in temperature and moisture [11-13].

We have produced plastinated structures like entire brains, cerebral hemispheres, livers, upper limbs. On their surfaces structures like tendons, nerves, vessels, gyri, sulci, 


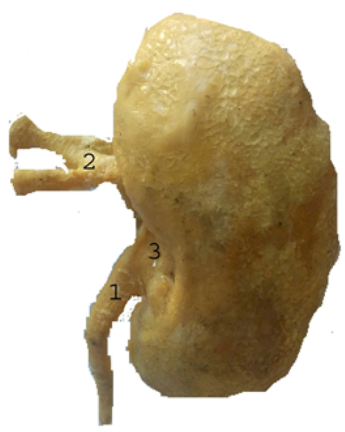

Fig. 6. Plastinated kidney: 1. ureter; 2. renal artery; 3. renal pelvis

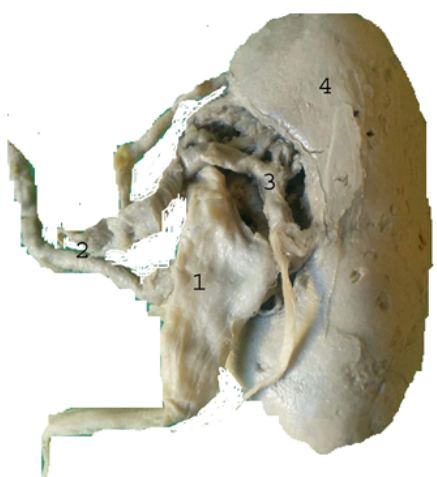

Fig. 7. Plastinated kidney.

1. renal pelvis and ureter;

2. renal artery; 3. renal vein; 4. renal cortex. can be seen, palpated, and measured at their real dimensions (fig. 5).

Parenchimatous viscera, like liver, spleen, kidney, are suitable for S10 Biodur plastination technique, the disadvantages are zero [14]. Especially on kidneys, ae highlighted renal segments, renal lobules, and renal vessels anatomical variants. Also, the renal pathology during evolution is suitable for this technique. Their size, shape, colour and macroscopically aspect were not modified and show ed a good colour and consistency. In other organs in which the fat tissue was not complete removed the later retained its yellow colour, without any changes in the viscus macroscopic appearance.

Although for the plastination of encephalon are recommended other techniques, the specimens of brain were plastinated through the S10 Biodur technique [14]. The colour and consistency were satisfied, even the shrinkage was obvious in this case (figs. 6 and 7).

The mostimportant chemical agents used for hardening and finishing the specimens preservation are rubbersilicones [21,22]. The last used and the most important, is S6 Biodur. S6 Biodur (gas cure) is a liquid containing silicate with a high saturated vapour pressure (boiling point 70 $80^{\circ} \mathrm{C}$ ). In order to react with the polymer of the impregnated specimen, the Biodur 56 must vaporize and the active vapour reacts with the silicone on the surface of the specimen. S6 Biodur commences a three-dimensional cross linking (side to side-linkage) of the molecules and hence imparts toughness or firmness to the specimen (von Hagens, 1984) [15].

The plastinated specimens have been displayed in our department museum and are useful as study modules. Using plastination, a library of specimens can be created displaying normal, variant, and pathological anatomy.

In fact, plastination can be considered as a reflection of the dissection process.

\section{Conclusions}

Plastination allows for preservation of specimen with completely visible surface and high durability. Plastinated specimens are odorless, not toxic and high degree mechanically resistant.

Our results highlighted the plastination technique advantages.

The main benefit is for students from disciplines such as anthropology, anatomy, urology and pathology.

The computerized reconstruction of pelvic floor plastinates has proven useful for various medical specialists and surgeons such as gynecologists, urosurgeons, and radiologists.
Customized vacuum chambers instead of currently available expensive industrial vacuum chambers are being considered for upcoming research work on plastination.

Our favourite method is using S10 Biodur technique.The short protocol for plastination is cost-effective, less timeconsuming, and can be easily performed with a simple setup without using costly equipment such as vacuum chambers and deep freezer.

Especially for the parenchimatous viscera (e.g. kidneys) this technique is the most apropiate for preservation.

Substances used for plastination are less toxic or nontoxic. Unless the formaldehide, they make the pieces durable, easy handled and very accurate.

There is no risk of infection when specimens are manipulated.

Aknoledgement: Present study was supported by funds kindly provided by Victor Babes University of Medicine and Pharmacy Timisoara, Romania, through P-III-C5-PCFI-2017/2018-03 Internal grantacronym UROVESSELS.

\section{References}

1.CHAYNES, P, MINGOTAUD, A,F, Analysis of Commercial plastination Agents, Surg Radiol Anat. Jun; 26, no.3, 2004,p.235-238.

2.OTTONE, N,E, CIRIGLIANO, V, BIANCHI, H,F, MEDAN, C,D, ALGIERI, R,D, BORGES, BRUM, G, FUENTES, R, New Contributions to the Development of a Plastination Technique at Room Temperature with Silicone, Anat Sci Int. Mar; 90, N0.2, 2015,p.126-135.

3.VON HAGENS, G. - Curing with the S10 Standard Technique, Technical leaflet. Anatomisches Institut 1, Universtat Heidelberg, 1984.

4.MAHAJ AN, A, AGARWAL, S, TIWARI, S, VASUDEVA, N. Plastination: An Innovative Method of Preservation of Dead Body for Teaching and Learning Anatomy. MAMC J Med Sci ,NO. 2, 2016, p .38-42.

5.BICKLEY, H,C, - Plastination: A new Technique for Anatomic Pathology and Forensic Science Pathology, Update Series, 16, NO. 1,1984, p.3437.

6.BICKLEY, H,C, ; VON HAGENS, G ; TOW NSEND, F,M, - An Improved Method for the Preservation of Teaching Specimens, Arch Path Lab Med., 105, 1981, p. 674.

7.VON HAGENS G. Heidelberg Plastination Folder: Collection of Technical Leaflets for Plastination. 2nd ed. Heidelberg: Anatomische Institut, Universitat; no. 2, 1986, p.1-6; 3, 1986, p.1-13; 4, 1986, p.1-20; 5, 1986, p.1-17.

8.RIEDERER, B,M. Plastination and Its Importance in Teaching Anatomy. Critical Points for Long-term Preservation of Human Tissue, J Anat, 224, 2014, p.309-315.

9.WEBER, W, WEIGLEIN, A, LATOORRE, R, HENRY, R,W. Polyster Plastination of Biological Tissue- P35 Technique, J Int Soc Plastination, 20, 2007, p.50-58.

10.DEJ ONG, K, HENRY, R,W, Silicone Plastination of Biological Tissue: Cold-Temperature Technique Biodur S10/S15 Technique and Products, J Int Soc Plastination, 22, 2007, p. 2-14.

11.WANG, Q, XU, S, TU, L, LIU, Y, ZHANG, M, Anatomic Continuity of Longitudinal Pharyngeal and Esophageal Muscles, Laryngoscope, 117, 2007, p.82-87.

12.PASHAEI, S. A Brief Review on the History, Methods and Applications of Plastination, Int J Morphol, 28, 2010, p.1075-1079.

13.KESSLER, R, Fixation Solutions for Color Preservation in Plastination, J Int Soc Plastination , 2, 1990, p. 4-9.

14.PENTEA, M, HULEA ,C, STANCU, A., BUTNARIU, M, CRISTINA, R, C., Developing the plastination laboratory for the technique S10, Mat. Plast. 53, no.1, 2016, p.150

15.WEIGLEIN, A. H. , HENRY, R ,W, Curing (Hardening, Polymerization) of the Polymer - Biodur S10, J Int Soc Plastination, 7, 1993, p.32 - 35. 16.ULMER D. Fixation: Key to Good Tissue Preservation, J Int Soc Plastination 8, 1994, p.7-10. 
17.HENRY, R,W, Polyester Plastination Techniques, Specific Troubles and Problems. Murcia, Spain, $12^{\text {th }}$ International Conference on Plastination, 2004, p.23-24.

18.BARNETT, R,I, LYONS, G,W, DRISCOLL, J,D, FORREST, W, J Improved Sectioning and Berlin Blue Staining of Whole Human Brain, Stain Technol, 55, 1980, p. 235-239.

19.ROSU, S., SIRBU, N. A., TATU, R. F., Contours Identification in Modelling Facial Silicone Epistasis, Mat. Plast., 51, no. 3, 2014, p.317 20. TATU, R. F., MARSAVINA, L., VOICONI, T., HURMUZ, M., TATU,C., UNGUREAN, C., ROSU, S., Reinforcement of Tibial Fixation in Anterior
Cruciate Ligament Reconstruction Using, Mat. Plast., 51,no. 4, 2014, p.460.

21.CRAINICEANU, Z., IANES, E., MATUSZ, P., BLOANCA, V., SELEACU, E., NARAD, V., NARAD, G., NODITI, G., BRATU, T., Innovative Method of Titanium Plate Use for Morphological and Functional Human Face Recontruction, Mat. Plast., 53, no. 3, 2016, p. 518

22.CAPLESCU, C., MARSAVINA, L., BORDEASU, I., SECHEI, R., M., The Fracture of Polyurethane Materials in the Presence of Stress Concentrators, Mat. Plast.,47, no.3, 2010, p. 379

Manuscript received: 15.12 .2016 